\title{
Neyraiella distinctus n. sp. (Oxyurida, Blattophilidae) Parasite of Nymphs of Gryllodes laplatae Sauss (Orthoptera, Gryllidae) in Argentina
}

\author{
Nora B Camino $/{ }^{+}$, Cristina de Villalobos* \\ Centro de Estudios Parasitológicos y de Vectores, Calle 2, 584, 1900 La Plata, Argentina *Facultad de Ciencias Naturales y \\ Museo, La Plata, Argentina
}

Neyraiella distinctus n. sp. was found parasitizing nymphs of the cricket Gryllodes laplatae Sauss in City Bell, Argentina. This species was characterized by having the excretory pore in the posterior end of the basal bulb, vulva protruding with one lip well developed in the 1/3 end of the body, anus of the female with wings, male with a single spicule without any sculpture, gubernaculum and bursa are absent, six pairs of genital papillae arranged in two preanal pairs, one adanal pair and three postanal pairs, and the tail appendage in both sexes was short and conic.

Key words: Neyraiella distinctus n. sp. - Oxyurida - parasite - cricket - taxonomy - Argentina

Sanchez (1947) described in Spain a parasite of Gryllotalpa europeus L. (Orthoptera: Gryllotalpidae), and placed it within the oxyurids. He created the genus Neyraiella and the new Family Neyraiellidae, with the type species Neyraiella neyrae.

Skrjabin et al. (1951,1954), Theodorides (1953), Basir (1956), Rao (1958), Kloss (1959), and Leibersperger (1960) accomplished a taxonomic revision of the oxyurids. These authors think that Serrano Sanchez (1947) makes a mistake when describing the males of $N$. neyrae with two spicules instead of one, and therefore considering $N$. neyrae as a synonym of Gryllophila skrjabini (Sergiev) Basir, 1956 and placing this species within the family Thelastomatidae.

Poinar (1975), modified the treatise on invertebrates of Skrjabin et al. (1966), and gave a new key for the Order Oxyurida. He separated the superfamilies Thelastomatoidea and Rhigonematoidae by the presence in the female of eight and four cephalic papillae, respectively. The males in the Thelastomatidae family present only one spicule, while in the Rhigonematidae they present either one or two rudimentary spicules. Based on these features, he established Neyraiella as a valid genus, placing it within the superfamily Rhigonematoidea, family Blattophilidae.

In this paper we report another new species of the genus Neyraiella, N. distinctus sp. n. parasite of Gryllodes laplatae Sauss (Orthoptera: Gryllidae) found in City Bell, Argentina.

\section{MATERIALS AND METHODS}

Nymphs of G. laplatae collected manually were kept in plastic containers. In the laboratory the techniques of Poinar (1975) were followed, consisting on cooling the nymphs to $5^{\circ} \mathrm{C}$ approximately $3 \mathrm{~min}$, and then dissecting

${ }^{+}$Corresponding author. Fax: +54-221-423.2327. E-mail: nemainst@cepave.com.ar

Received 28 June 2001

Accepted 19 December 2001 them under electronic microscope in Petri dishes with distilled water. Nematodes (males and females) were extracted from the intestine stomodeus and were killed in distilled water in a double boiler during $2 \mathrm{~min}$. Later they were kept $48 \mathrm{~h}$ in a solution of 50\% TAF and 50\% distilled water, and then fixed in pure TAF. Measurements and drawings were made with a Zeiss microscope with camera lucida. Measurements given in the description belong to the male holotype and female allotype, the range of measurements of the paratypes are given between parentheses.

\author{
RESULTS \\ Order Oxyurida \\ Superfamily Rhigonematoidea \\ Family Blattophilidae \\ Genus Neyraiella \\ Neyraiella distinctus sp. $\mathrm{n}$.
}

(Fig. 1 A-F)

Description: small and white nematodes. Annulated cuticle. Mouth surrounded by four cephalic papillae. Bucal cavity with small denticles (Fig. 1C). Small and pyriform amphids. Esophagus long with indistinct pseudobulb (Fig. 1D,E). Basal bulbs with valves. Excretory pore opening behind the basal bulb. Vulva protruding with vulval lips developed and placed in the posterior third of the body (Fig. 1A). Vagina cylindrical and long directed to the posterior end. Female prodelphic. Uterus with strangulations forming true capsules, each one containing a single egg. Female anus with wings. Eggs oval, with smooth shell, without byssum and individual (Fig. 1A). Male with a simple spicule not sculptured, without gubernaculum or bursa (Fig. 1F). Genital pore opens in a protuberance. Six pairs of genital papillae as follows: two preanal pairs, one pair adanal and three pairs postanal, the last of which is placed at the base of the tail appendage (Fig. 1B). Tail in both sexes short and conic.

Male ( $\mathrm{n}=15)$ - Total body length: $2.050 \mu \mathrm{m}(1.980-2.120)$, cephalic diameter at level of papillae: $18.8 \mu \mathrm{m}(16.45-21.15)$; maximum body diameter: $108.1 \mu \mathrm{m}$ (91.65-124.55); distance from anterior end to base of basal bulb: $245 \mu \mathrm{m}$ (220-270); spicles length: $36.42 \mu \mathrm{m}$ (35.25-37.60); tail length: 17.62 $\mu \mathrm{m}(14.10-21.15)$. 
Female $(\mathrm{n}=20)$ - Total body length: $4.420 \mu \mathrm{m}(4.280-4.560)$; cephalic diameter at level of papillae: $24.67 \mu \mathrm{m}(23.5-25.85)$; body diameter at level of vulva: $272.5 \mu \mathrm{m}$ (265-280); maximum body diameter: $440 \mu \mathrm{m}(400-480)$; distance from anterior end to base of basal bulb: $515 \mu \mathrm{m}$ (460-570); distance from vagina to anus: $675 \mu \mathrm{m}(610-740)$; V: $82.69 \%$ (82.6782.71); tail length: $29.37 \mu \mathrm{m}(25.85-32.9)$; length and width of eggs: $85.77 \mu \mathrm{m}(70.50-101.05) \times 32.9 \mu \mathrm{m}(30.55-35.25)$. Type locality: City Bell, La Plata, Buenos Aires Province, Argentina.
Type Host: nymphs of Gryllodes laplatae Sauss (Orthoptera: Gryllidae).

Type material: deposited in the Helmintological collection, Museo de La Plata, La Plata, Argentina, no. 4848.

\section{DISCUSSION}

We agree with Poinar (1975) considering valid the genus Neyraiella. $N$. distinctus sp. n. shares with the single species of the genus hitherto described, N. neyrae Sanchez, 1947, the following characters: transverse cu-
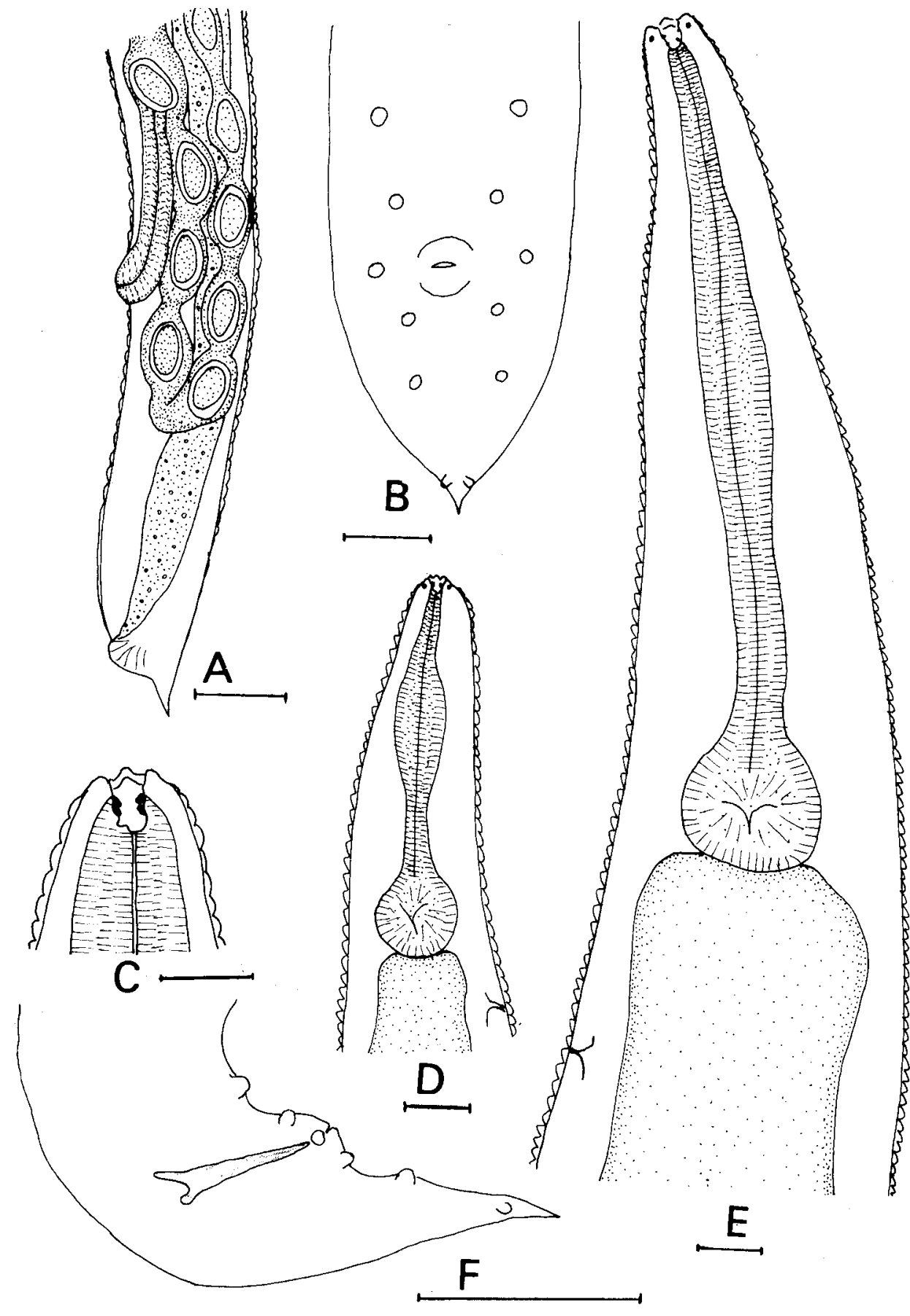

Neyraiella distinctus n. sp. A: posterior end of the female, vagina, eggs and anus; B: posterior end of the male, ventral view; C: anterior end of the female; D: stoma of the female; E: anterior end of the male; F: posterior end of the male, lateral view. Bars $=50 \mu \mathrm{m}$ 
ticle striae, mouth surrounded by four papillae, amphids small and pyriform, uterine rami with stranglings forming capsules for each egg, eggs with smooth shell, in the male, protruding genital cone, and the presence in both sexes of a short and conic tail.

$N$. neyrae differs from our new species in the following characters: bucal cavity with two ribs forming a fork, and ending each one in a denticle, the excretory pore opens much behind the base of the esophagus, the vulva is not protruding, the vagina isshort, the eggs are large $(150 \mu \mathrm{m}$ $\mathrm{x} 70 \mu \mathrm{m})$, the spicule is longer $(63 \mu \mathrm{m})$ and it lacks the adanal pair of papillae.

Because of the mentioned characters we regard $N$. distinctus sp. n. as a new species.

\section{REFERENCES}

Basir MA 1956. Oxyuroid parasites of Arthropoda. Zoologica 38: $1-79$.

Kloss GR 1959. Nematoides parásitos de Gryllotalpoidea (Orthoptera) do Brasil. Mem Inst Oswaldo Cruz 57: 137-170.

Leibersperger E 1960. Die Oxyuroidea der euroäischen
Arthropoden. Parasitol Schriftenr Jena 11: 1-150.

Poinar Jr GO 1975. Entomogenous Nematodes. A Manual and Host List of Insects Nematode Associations, EJ Brill, Leiden, $317 \mathrm{pp}$.

Rao PN 1958. Studies on the nematode parasites of insects and other arthropods. Arquiv Mus Nac Rio de Janeiro 46: 3384.

Sanchez AS 1947. Nematodes parasitas intestinales de los artropodos en España. Rev Iber Parasitol 7: 279-332.

Skrjabin KJ, Schikhobalova NP, Lagodovskaya EA 1966. [Manual of Nematology] Nauka, SSSR, 538 pp. (in russian).

Skrjabin KJ, Schikhobalova NP, Mosgovi AA, 1951. [Descriptive catalogue of nematodes parasites]. Acad Cs Urss Lab Helmintol Moscu 2: 631 (in russian).

Skrjabin KJ, Schikhobalova NP, Sobolev AH, Paramonov AA, Sularikov VE 1954. [Descriptive catalogue of nematodes parasites]. Acad Cs Urss Lab Helmintol Moscu 4: 927 (in russian).

Theodorides J 1953. Sur un nématode parasite de la courtilière Gryllotalpa gryllotalpa (L.) (Orthoptera:Gryllotalpidae): Gryllophila skrjabini (Sergiev) Basir var. ovipolita nov. (Oxyuroidea, Thelastomatidae). Ann Parasit Hum Comp 28: 300-304. 